\title{
Pengaruh Teknik Pembelajaran Value Clarification terhadap Hasil Belajar Mata Pelajaran Aqidah Akhlak Materi Pembelajaran Iman kepada Kitab- Kitab Allah SWT
}

\author{
Rukmanah $^{1 \star}$, Suhartono ${ }^{2 \star}$, dan Supangat ${ }^{3 \star}$ \\ ${ }^{1}$ STKIP Nurul Huda \\ ${ }^{2}$ Dosen STKIP Nurul Huda OKU Timur \\ ${ }^{3}$ Dosen STKIP Nurul Huda OKU Timur \\ "E-mail: rukmanah@gmail.com \\ "E-mail: suhartono@stkipnurulhuda.ac.id \\ "E-mail: Supangat@stkipnurulhuda.ac.id
}

\begin{abstract}
Abstrak
Penelitian ini dilatarbelakangi kurang efektifnya pembelajaran Aqidah Akhlak di kelas VIII MTs Nurul Huda Sukaraja. Tujuan penelitian ini adalah untuk mengetahui pengaruh teknik pembelajaran Value Clarification terhadap hasil belajar mata pelajaran Aqidah Akhlak materi Iman Kepada Kitab-kitab Allah SWT siswa kelas VIII MTs Nurul Huda Sukaraja. Penelitian komparatif dilaksanakan menggunakan desain eksperimen yaitu True Experimental Design yaitu Posstest Only Control Design. Sampel penelitian ini adalah seluruh siswa kelas VIII-2 dan VIII-3 MTs Nurul Huda Sukaraja yang berjumlah 53 orang. Sebagai kegiatan akhir analisis data penelitian dapatlah disimpulkan Pertama: Hasil belajar mata pelajaran Aqidah Akhlak materi Iman Kepada Kitabkitab Allah SWT siswa yang menerapkan teknik pembelajaran Value Clarification di kelas VIII MTs Nurul Huda Sukaraja adalah sedang. Kedua: Hasil belajar mata pelajaran Aqidah Akhlak materi Iman Kepada Kitab-kitab Allah SWT siswa yang tidak menerapkan teknik pembelajaran Value Clarification di kelas VIII MTs Nurul Huda Sukaraja adalah sedang. Ketiga: Terdapat pengaruh penerapan teknik pembelajaran Value Clarification terhadap hasil belajar mata pelajaran Aqidah Akhlak materi Iman Kepada Kitab-kitab Allah SWT siswa kelas VIII MTs Nurul Huda Sukaraja.
\end{abstract}

Kata kunci: Teknik Pembelajaran Value Clarification, Hasil Belajar Akidah Akhlak

\section{PENDAHULUAN}

Pendidikan Agama Islam di lembaga-lembaga pendidikan keagamaan seperti di Madrasah Tsanawiyah dibagi menjadi sub-sub mata pelajaran secara khusus yaitu Aqidah Akhlak, al-Qur'an Hadis, Fiqih dan Sejarah Kebudayaan Islam. Aqidah Akhlak sebagai salah satu bentuk Pendidikan Agama Islam berisi materi-materi pembelajaran tentang pembinaan keimanan dan pembentukan akhlak siswa. Hal tersebut sebagaimana dijelaskan dalam kurikulum pembelajaran Aqidah Akhlak sebagai berikut:

Mata pelajaran Aqidah dan Akhlak tidak hanya mengantarkan siswa untuk menguasai pengetahuan dan pemahaman tentang Aqidah dan Akhlak dalam ajaran Islam, melainkan yang terpenting adalah bagaimana siswa dapat mengamalkan Aqidah dan Akhlak itu dalam kehidupan sehari-hari. Mata pelajaran Aqidah dan Akhlak menekankan keutuhan dan keterpaduan antara pengetahuan, sikap, dan perilaku atau lebih menekankan pembentukan ranah efektif dan psikomotorik yang dilandasi oleh ranah kognitif (Madjid, 2004: 131).

Penjelasan di atas memberikan pengertian bahwa pembelajaran Aqidah Akhlaq merupakan upaya sadar dan terencana dalam menyiapkan siswa untuk mengenal, memahami, menghayati dan mengimani Allah dan merealisasikannya dalam perilaku Akhlak mulia dalam kehidupan sehari-hari melalui kegiatan bimbingan, pengajaran, latihan, penggunaan pengalaman dan pembiasaan. Adapun dasar pelaksanaan pembelajaran Aqidah Akhlak adalah hadis Nabi Muhammad SAW sebagai 
berikut:

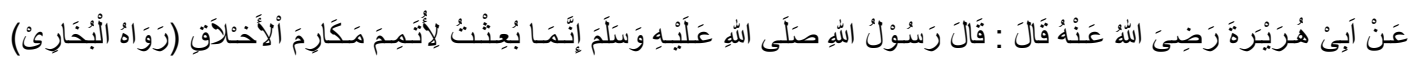

Artinya:

Dari Abu Hurairah ra berkata: sesungguhnya Nabi saw bersabda "Sesungguhnya aku diutus untuk menyempurnakan akhlak" (H.R. Muslim) (An-Nawawi, t.t.: 13).

Hadits di atas menunjukkan bahwa pembelajaran Aqidah Akhlak kelanjutan dari perjuangan Nabi Muhammad SAW dalam membina akhlak manusia. Pembelajaran Aqidah Akhlak dilaksanakan untuk memperkuat rasa keimanan siswa yang diiringi dengan terbinanya akhlak mulia. Melalui pembelajaran Aqidah Akhlak diharapkan siswa menjadi pribadi-pribadi muslim kamil yang memiliki dasar aqidah kuat dan mampu menampilkan perilaku atau akhlak yang baik dalam kehidupan seharihari. Oleh karena itu, ketercapaian hasil belajar mata pelajaran Aqidah Akhlak secara maksimal merupakan suatu keharusan dalam pelaksanaan Aqidah Akhlak.

Berkaitan hasil belajar, Poerwanto (2009: 28) menjelaskan "Hasil belajar adalah prestasi yang dicapai oleh seseorang dalam usaha belajar sebagaimana yang dinyatakan dalam nilai raport". Hasil belajar adalah suatu bukti keberhasilan belajar atau kemampuan seseorang siswa dalam melakukan kegiatan belajarnya sesuai dengan bobot yang dicapainya. Pencapaian hasil belajar dipengaruhi oleh berbagai faktor yang salah satunya adalah teknik pembelajaran yang diterapkan oleh guru. Hal tersebut sebagaimana dikemukakan Hawi (2012: 15) bahwa "Model, metode, teknik dan strategi pembelajaran merupakan faktor ekstern yang sangat menentukan tingkat keberhasilan belajar siswa".

Arti penting pemilihan teknik pembelajaran secara tepat terlebih pada pembelajaran Aqidah Akhlak kurang mendapatkan perhatian dari berbagai pihak khususnya oleh guru. Hal tersebut ditambah dengan rendahnya minat siswa dalam mengikuti pembelajaran Aqidah Akhlak mengingat mata pelajaran Aqidah Akhlak tidak menentukan kelulusan siswa. Hal tersebut sebagaimana terjadi di kelas VIII Madrasah Tsanawiyah Nurul Huda Sukaraja Kecamatan Buay Madang Kabupaten OKU Timur.

Berdasarkan hasil pengamatan pendahuluan pada mata pelajaran Akidah Akhlak diketahui bahwa teknik pembelajaran yang diterapkan di oleh guru cenderung menggunakan metode dan teknik pembelajaran yang kovensioal. .Penerapan teknik pembelajaran konvensional mengakibatkan terjadinya komunikasi satu arah dari guru kepada siswa tanpa adanya balikan dari siswa kepada guru . Pada pembelajaran menggunakan teknik pembelajaran konvensional siswa hanya mendengarkan penjelasan guru dan kadangkala menjawab pertanyaan dari guru. (kegiatan pembelajaran berpusat pada guru / teacher centred)

Keadaan pembelajaran Aqidah Akhlak di kelas VIII MTs Nurul Huda Sukaraja sebagaimana tersebut berimplikasi pada rendahnya pencapaian hasil belajar siswa. Rendahnya hasil belajar mata pelajaran Aqidah Akhlak siswa kelas VIII MTs Nurul Huda Sukaraja ditunjukkan dari hasil ujian tengah semester yang dilaksanakan. Dokumentasi nilai murni ujian tengah semester siswa kelas VIII menunjukkan bahwa dari 116 siswa hanya terdapat 53 siswa $(45,67 \%)$ yang memperoleh nilai $\geq 70$, sedangkan 63 siswa $(54,31 \%)$ belum mencapai ketuntasan dengan memperoleh nilai $<70$ (Dokumentasi Nilai Murni Ujian Tengah Semester).

Data hasil dokumentasi nilai ujian tengah semester siswa kelas VIII MTs Nurul Huda Sukaraja pada mata pelajaran Aqidah Akhlak tersebut menunjukkan bahwa hasil belajar Aqidah Akhlak siswa masih tergolong rendah. Oleh karena itu, peneliti bermaksud mengadakan suatu penelitian berbentuk eksperimen. Sesuai hasil identifikasi masalah yang menunjukkan bahwa siswa kurang termotivasi mengikuti pembelajaran Aqidah Akhlak yang disampaikan menggunakan teknik pembelajaran ceramah serta hafalan, maka pada penelitian ini digunakan.

Data hasil dokumentasi nilai murni ujian semester siswa kelas VIII MTs Nurul Huda Sukaraja pada mata pelajaran Pendidikan Agama Islam tersebut menunjukkan bahwa hasil belajar Aqidah Akhlak siswa masih tergolong rendah. Oleh karena itu, peneliti bermaksud mengadakan suatu penelitian berbentuk eksperimen. Sesuai hasil identifikasi masalah yang menunjukkan bahwa siswa 
kurang termotivasi mengikuti pembelajaran Aqidah Akhlak yang disampaikan menggunakan teknikteknik pembelajaran konvensional seperti ceramah serta hafalan, maka pada penelitian ini digunakan teknik pembelajaran yang lebih komunikatif yaitu teknik pembelajaran Value Clarification.

Elmubarok (2009: 70) berpendapat bahwa, "Value Clarification Tecnique atau teknik pembelajaran klarifikasi nilai merupakan teknik pembelajaran yang memberi penekanan usaha membantu siswa mengkaji materi pembelajaran untuk meningkatkan kesadaran akan nilai-nilai yang terkandung pada materi pembelajaran". Teknik pembelajaran Value Clarification merupakan sebuah cara menanamkan dan mengungkapkan nilai-nilai tertentu dari siswa. Teknik pembelajaran Value Clarification dilakukan dengan mengupayakan pemahaman siswa terhadap nilai-nilai yang terkandung pada materi pembelajaran.

Berdasarkan penjelasan tentang teknik pembelajaran Value Clarification, peneliti mengujicobakan teknik pembelajaran Value Clarification pada pembelajaran Aqidah Akhlak di dua kelas VIII MTs Nurul Huda Sukaraja. 1 kelas dijadikan sebagai kelas eksperimen dan 1 kelas dijadikan sebagai kelas kontrol. Pemilihan teknik pembelajaran Value Clarification didasarkan pada asumsi bahwa Aqidah Akhlak merupakan pendidikan nilai yaitu pendidikan yang diselenggarakan untuk menanamkan nilai-nilai ajaran Islam pada diri siswa. Aqidah Akhlak tidak dapat dilaksanakan hanya dengan memberikan pengetahuan terhadap nilai-nilai ajaran agama Islam, namun harus memberikan pemahaman kepada siswa tentang hakikat dari nilai-nilai yang terdapat pada materi Aqidah Akhlak. Dengan demikian Aqidah Akhlak harus dilaksanakan menggunakan teknik-teknik tertentu yang sesuai dengan karakteristik Aqidah Akhlak seperti teknik pembelajaran Value Clarification. Oleh karena itu, pada penelitian ini digunakan teknik pembelajaran Value Clarification sebagai teknik pembelajaran untuk memperbaiki proses serta hasil belajar mata pelajaran Aqidah Akhlak siswa kelas VIII MTs Nurul Huda Sukaraja. Untuk mengetahui hasil belajar mata pelajaran Aqidah Akhlak materi Iman Kepada Kitab-kitab Allah SWT siswa yang menerapkan teknik pembelajaran Value Clarification di kelas VIII MTs Nurul Huda Sukaraja

\section{Pengertian Teknik Pembelajaran Value Clarification}

Kegiatan pembelajaran dilaksanakan menggunakan berbagai pedoman tertentu yang disebut metode pembelajaran. Metode pembelajaran dapat dilaksanakan melalui berbagai teknik yang disebut teknik pembelajaran. Salah satu teknik pembelajaran yang sering digunakan untuk menyampaikan materi adalah teknik pembelajaran Value Clarification atau Value Clarification Technique (VCT). Djahiri (2007: 36) menjelaskan pengertian teknik pembelajaran Value Clarification dengan menyatakan:

Teknik pembelajaran Value Clarification merupakan singkatan dari Value Clarification Technique. Kata Value berarti nilai yang berasal dari bahasa latin yaitu Vlure berarti baik atau kuat. Sedangkan arti Clarification Technique adalah teknik mengklarifikasi atau memperjelas, mengungkapkan, memperinci nilai. Jadi teknik pembelajaran Value Clarification adalah teknik mengklarifikasi nilai atau teknik pengungkapan nilai. Dengan klarifikasi nilai, siswa tidak disuruh menghapal dan tidak disuapi dengan nilai-nilai yang sudah dipilihkan pihak lain, melainkan dibantu untuk menemukan, menganalisis, memilih, mengembangkan, mengambil sikap dan mengamalkan nilai-nilai hidupnya sendiri.

Berdasarkan pengertian etimologis tersebut diketahui bahwa teknik pembelajaran Value Clarification berarti teknik pembelajaran yang dilaksanakan dengan memperkenalkan cara-cara mengklarifikasi nilai yang terdapat pada materi pembelajaran. Pengertian tersebut diperkuat Harmianto (2012: 37) mengungkapkan, "Teknik pembelajaran Value Clarification adalah teknik pembelajaran yang menekankan pada penanaman berbagai nilai sesuai materi pembelajaran pada diri siswa". Pendapat tersebut sejalan dengan Taniredja (2011: 87) yang menjelaskan sebagai berikut:

Teknik pembelajaran Value Clarification atau sering disingkat VCT dapat diartikan sebagai teknik pengajaran untuk membantu siswa dalam mencari dan menentukan suatu

Rukmanah $^{1}$, Suhartono ${ }^{2}$, dan Supangat ${ }^{3}$ 
nilai yang dianggap baik dalam menghadapi suatu persoalan melaui proses menganalisis nilai yang sudah ada dan tertanam dalam diri siswa.

Penjelasan teknik pembelajaran Value Clarification di atas menunjukkan bahwa teknik pembelajaran Value Clarification merupakan bentuk teknik pembelajaran sikap dengan tujuan agar siswa memahami berbagai nilai-nilai yang terdapat pada materi pembelajaran. Teknik pembelajaran Value Clarification dilaksanakan dengan cara mengembangkan berbagai nilai sesuai materi pembelajaran dengan tujuan siswa dapat memahami dan mengamalkan nilai tersebut dalam kehidupan sehari-hari.

Berdasarkan pengertian-pengertian teknik pembelajaran Value Clarification dapat disimpulkan bahwa teknik pembelajaran Value Clarification merupakan teknik pembelajaran yang dilaksanakan melalui proses penanaman nilai dengan cara analisis nilai yang sudah ada sebelumnya dalam diri siswa kemudian menyelaraskannya dengan nilai-nilai baru yang hendak ditanamkan. Pembelajaran menggunakan teknik pembelajaran Value Clarification adalah pembelajaran bukan hanya bertujuan untuk mencapai pendidikan kognitif saja, akan tetapi juga bertujuan untuk mencapai dimensi lainnya yaitu sikap maupun keterampilan afektif berhubungan dengan volume sulit diukur karena menyangkut kesadaran seseorang yang tumbuh dalam diri.

\section{Langkah-langkah Penerapan Teknik Pembelajaran Value Clarification}

Sanjaya (2011: 284) secara terperinci menyebutkan langkah-langkah pelaksanaan teknik pembelajaran Value Clarification sebagai berikut:

a. Guru membuka pelajaran dengan menanamkan nilai-nilai tertentu seperti mengucapkan salam pembuka, menanyakan kabar siswa maupun mengajak siswa berdoa sebelum memulai pembelajaran.

b. Guru memberikan apersepsi dengan menanyakan nilai-nilai tertentu yang terdapat pada materi pembelajaran akan dipelajari.

c. Guru memberikan motivasi dengan cara-cara sugestif seperti mengajak siswa melakukan permainan atau gerakan-gerakan tertentu.

d. Guru menjelaskan kepada siswa bahwa mereka akan ber-Value Clarification Technique.

e. Guru menjelaskan langkah-langkah kegiatan pembelajaran yang akan dilaksanakan menggunakan Value Clarification Technique.

f. Guru menyebutkan indikator keberhasilan pembelajaran serta nilai-nilai yang harus dipahami siswa setelah kegiatan pembelajaran.

g. Guru membagi siswa dalam beberapa kelompok kecil dengan berpedoman pada pembelajaran kooperatif yaitu satu kelompok terdiri atas 3 - 4 orang siswa.

h. Guru menjelaskan materi pembelajaran secara singkat dan mendeskripsikan Aqidah Akhlak berbagai nilai yang terdapat pada materi pembelajaran.

i. Guru memberikan kebebasan memilih yaitu memberikan kebebasan kepada siswa untuk memilih satu nilai tertentu yang terdapat pada materi pembelajaran untuk dianalisis lebih mendalam secara berkelompok.

j. Setiap siswa atau kelompok siswa diberikan tugas untuk mendiskusikan nilai tertentu yang menjadi pilihan kelompoknya dan mendeskripsikan Aqidah Akhlak penjabaran nilai yang dipilih beserta relevansinya dengan materi pembelajaran.

k. Setiap kelompok mempresentasikan hasil diskusi kelompoknya masing-masing tentang nilai tertentu yang dipilih.

I. Melaksankan dialog terpimpin melalui perntanyaan guru baik secara individual, kelompok maupun secara klasikal.

m. Melakukan evaluasi untuk menganalisis pemahaman siswa terhadap nilai yang terdapat pada materi pembelajaran.

n. Menyimpulkan, merefleksi, dan memberikan penguatan.

\section{Kelebihan dan Kelemahan Value Clarification Technique}

Setiap teknik pembelajaran memiliki berbagai kelebihan dan kelemahan tertentu. Demikian halnya dengan teknik pembelajaran Value Clarification pada implementasinya juga memiliki berbagai kelebihan dan kelemahan. Berkaitan kelebihan teknik pembelajaran Value Clarification disebutkan Taniredja (2011: 91) sebagai berikut:

a. Mampu membina dan menanamkan nilai dan moral pada ranah internal side. 
b. Mampu mengklarifikasi atau menggali dan mengungkapkan isi pesan materi yang disampaikan selanjutnya akan memudahkan bagi guru untuk menyampaikan makna, pesan nilai maupun moral.

c. Mampu mengklarifikasi dan menilai kualitas nilai moral diri siswa, melihat nilai yang ada pada orang lain dan memahami nilai moral yang ada dalam kehidupan nyata.

d. Mampu mengundang, melibatkan, membina dan mengembangkan potensi diri siswa terutama mengembangkan potensi sikap.

e. Mampu memberikan sejumlah pengalaman belajar dari berbagai kehidupan.

f. Mampu menangkal, meniadakan, mengintervensi dan memadukan berbagai nilai moral dalam sistem nilai dan moral yang ada dalam diri seseorang.

g. Memberi gambaran nilai moral yang patut diterima dan menuntun serta memotivasi untuk hidup layak dan bermoral tinggi.

Berdasarkan kelebihan-kelebihan sebagimana tersebut diketahui bahwa kelebihan utama dari teknik pembelajaran Value Clarification adalah terbinanya moral siswa serta meresapnya nilai-nilai tertentu pada diri siswa. teknik pembelajaran Value Clarification memberikan kemudahan bagi guru untuk menanamkan nilai-nilai luhur yang terdapat pada materi pembelajaran sehingga dapat menjadi satu kebiasaan yang melekat pada diri siswa. Pembelajaran menggunakan teknik pembelajaran Value Clarification menjadikan siswa tidak hanya memahami materi pembelajaran secara teoretis, namun siswa dapat memahami nilai-nilai yang terkandung pada materi pembelajaran untuk diterapkan dalam kehidupan sehari-hari.Selain memiliki kelebihan-kelebihan sebagaimana tersebut, Taniredja (2011: 91) menyebutkan kelemahan-kelemahan teknik pembelajaran Value Clarification sebagai berikut:

a. Apabila guru tidak memiliki kemampuan melibatkan siswa dengan keterbukaan, saling pengertian dan penuh kehangatan maka siswa akan memunculkan sikap semu atau imitasi. Siswa akan menjadi siswa yang sangat baik ideal patuh dan penurut namun hanya bertujuan untuk menyenangkan guru atau memperoleh nilai yang baik.

b. Sistem nilai yang dimiliki dan tertanam pada guru, siswa dan masyarakat kurang atau tidak baku sehingga mengganggu tercapainya target nilai baku yang ingin dicapai.

c. Sangat dipengaruhi oleh kemampuan guru dalam mengajar terutama memerlukan kemampuan bertanya tingkat tinggi yang mampu mengungkap dan menggali nilai yang ada pada diri siswa.

d. Memerlukan kreativitas guru dalam menggunakan media yang tersedia di lingkungan terutama yang aktual dan faktual sehingga dekat dengan kehidupan sehari-hari siswa.

Penjelasan sebagaimana tersebut menunjukkan bahwa kelemahan utama dari teknik pembelajaran Value Clarification adalah pada penanaman nilai yang bersifat abstrak dalam diri siswa. Nilai merupakan sesuatu yang esensial pada sebuah objek seperti materi pembelajaran sehingga pengenalan, pemahaman, serta penanaman nilai materi pembelajaran merupakan suatu hal yang sulit untuk dilakukan. Oleh karena itu, teknik pembelajaran Value Clarification memerlukan kreativitas guru dalam menemukan berbagai langkah strategis untuk dapat menanamkan nilai pada diri siswa.

\section{METODE/EKSPERIMEN}

Metode penelitian yang digunakan adalah penelitian eksperimen. Penelitian eksperimen dilakukan dengan mengujicobakan teknik pembelajaran Value Clarification pada pembelajaran Aqidah Akhlak. Penelitian ditujukan untuk mengetahui besar pengaruh teknik pembelajaran Value Clarification terhadap hasil belajar Aqidah Akhlak siswa. Ada tidaknya pengaruh teknik pembelajaran Value Clarification terhadap hasil belajar Aqidah Akhlak siswa diketahui dengan cara membandingkan hasil belajar Aqidah Akhlak siswa yang menerapkan teknik pembelajaran Value Clarification dan tanpa menerapkan teknik pembelajaran Value Clarification.

. Desain penelitian digunakan adalah True Experimental Design atau penelitian eksperimen yang sesungguhnya. Menurut Suryabrata (2010: 32), metode eksperimen sungguhan adalah menyelidiki kemungkinan hubungan sebab-akibat dengan desain di mana secara nyata ada kelompok

Rukmanah $^{1}$, Suhartono ${ }^{2}$, dan Supangat ${ }^{3}$ 
perlakuan dan kelompok kontrol dan membandingkan hasil perlakuan dengan kontrol secara ketat. Validitas internal dan eksternal cukup utuh.

Desain penelitian True Experimental Design dilaksanakan sistem Postest Only Control Group Design. Dalam model rancangan ini, kelompok eksperimen dan kelompok kontrol dibentuk dengan prosedur random, sehingga keduanya dapat dianggap setara. Selanjutnya kelompok eksperimen diberikan perlakuan. Setelah perlakuan telah diberikan dalam jangka waktu tertentu, maka setelah itu dilakukan pengukuran variabel terikat pada kedua kelompok tersebut, dan hasilnya dibandingkan perbedaannya sebagaimana gambar.1.

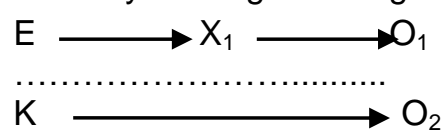

Gambar . 1. Desain Post-test dengan Kelompok yang Diacak (Sugiyono, 2010: 78)

E : Kelompok eksperiman.

$\mathrm{K}$ : Kelompok kontrol.

$\mathrm{X}_{1}$ : Perlakuan eksperimen.

$\mathrm{O}_{1} \quad$ : Posttest eksperimen.

$\mathrm{O}_{2}$ : Posttest kontrol.

\section{Populasi dan Sampel Penelitian}

Populasi merupakan seluruh data yang menjadi perhatian dalam suatu ruang lingkup dan waktu yang ditentukan. Hal tersebut sebagaimana dikemukakan Nawawi (dalam Margono, 2010: 18) menjelaskan, "Populasi adalah keseluruhan objek penelitian yang terdiri dari manusia, benda, hewan, tumbuh-tumbuhan, gejala-gejala, nilai tes, atau peristiwa sebagai sumber data yang memiliki karakteristik tertentu".. Yang menjadi populasi dalam penelitian ini adalah siswa kelas VIII-1, VIII-2, VIII-3, VIII-4 MTs Nurul Huda, siswa laki-laki sebanyak 48 orang, sedangkan siswa perempuan sebanyak 57 orang, jumlah semuanya adalah 105 orang.

Margono (2010:121) menjelaskan, "Sampel adalah bagian dari populasi sebagai contoh yang diambil menggunakan cara-cara tertentu". Arikunto (2010:174) mengemukakan, "Sampel adalah sebagian atau wakil populasi yang diambil untuk menggeneralisasikan hasil penelitian". Berdasarkan pengertian sampel di atas dapat disimpulkan bahwa sampel adalah wakil dari populasi untuk diteliti.

Teknik pengambilan sampel dalam penelitian ini adalah teknik klaster (cluster) yaitu penarikan dari populasi yang telah dikelompokkan terlebih dahulu (Anggoro, 2007:47). Pada penelitian ini klaster dilakukan terhadap kelompok kelas yaitu kelas VIII-1, kelas VIII-2, kelas VIII3 , kelas VIII-4. Setelah dilakukan pengelompokan langkah selanjutnya adalah mengambil nomor kelompok secara acak. Berdasarkan pengambilan sampel tersebut, nomor kelompok terambil adalah nomor 2 dan 3 sehingga sampel penelitian ini adalah siswa kelas VIII-2 dan VIII-3 MTs Nurul Huda Sukaraja.

\begin{tabular}{|c|c|l|c|}
\hline No & Kelas & \multicolumn{1}{|c|}{ Kelompok } & Jumlah \\
\hline 1 & VIII-2 & $\begin{array}{l}\text { Eksperimen menerapkan teknik pembelajaran } \\
\text { Value Clarification }\end{array}$ & 27 Siswa \\
\hline 2 & VIII-3 & $\begin{array}{l}\text { Kontrol tanpa menerapkan teknik pembelajaran } \\
\text { Value Clarification }\end{array}$ & 26 Siswa \\
\hline Jumlah & 53 Siswa \\
\hline
\end{tabular}

\section{Teknik Pengumpulan Data}

Teknik pengumpulan data dalam penelitian dengan menggunakan dua cara yakni teknik tes, dan teknik dokumentasi.

Instrumen tes pada penelitian ini berupa multiple choice atau pilihan ganda dengan menggunakan sistem incomplete statements dan questioning. Sistem incomplete statements dilakukan dengan menugaskan siswa memilih jawaban untuk melengkapi suatu kalimat, 
sedangkan sistem questioning dilakukan dengan menugaskan siswa menjawab pertanyaan dengan memilih jawaban yang tersedia. Tes disusun sebanyak 25 nomor dengan 4 opsi jawaban yaitu a, b, c, dan d. Bobot setiap soal adalah 1 jika terjawab benar dan 0 jika salah. Oleh karena itu, skor maksimal yang dapat diperoleh siswa adalah 25. Penilaian terhadap hasil tes siswa dilakukan menggunakan rumus berikut:

$$
\text { Nilai }=\frac{\text { Skor Diperoleh }}{\text { Skor Maksimal }} \times 100 \text { (Dantes, 2012: 96). }
$$

Keterangan:

Skor diperoleh : Skor hasil tes siswa.

Skor maksimal : Bobot skor dikalikan dengan jumlah soal

Dokumentasi merupakan teknik pengumpulan data yang dilakukan dengan cara mengumpulkan berbagai informasi dalam berbagai bentuk yang berhubungan masalah penelitian. Hal tersebut sebagaimana dikemukakan Arikunto (2010: 274) bahwa "Dokumentasi adalah mencari data mengenai hal-hal atau variabel yang berupa catatan, transkrip, buku, surat kabar, majalah, prasasti, notulen rapat, legger, agenda dan sebagainya". Berdasarkan penjelasan tersebut, dokumentasi pada penelitian ini dilakukan dengan mengumpulkan berbagai informasi yang berhubungan langsung dengan sampel penelitian yang meliputi absensi siswa serta daftar nilai siswa dalam legger.

\section{Teknik Analisis Data}

Kegiatan utama penelitian adalah melakukan analisis terhadap berbagai data yang telah dikumpulkan. Analisis data pada penelitian ini dilakukan dengan langkah-langkah sebagai berikut:

\section{a. Menghitung Rata-rata Data}

Pada penelitian ini untuk mengetahui nilai rata-rata dari hasil belajar siswa menggunakan nilai rata-rata hitung atau (arithmetic mean) yang sering disingkat dengan mean (Sudijono,2010: 81). Rata-rata digunakan adalah rata-rata simpangan dengan menggunakan rumus berikut:

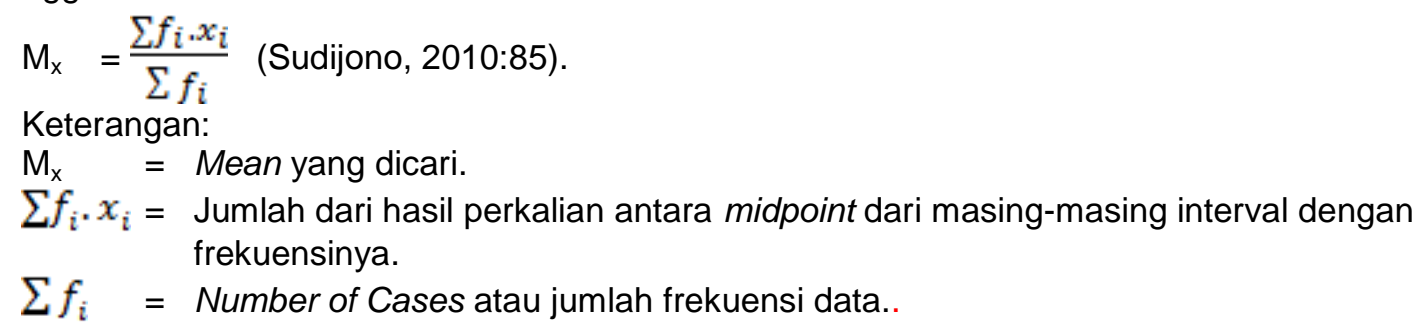

\section{b. Standar Deviasi}

Standar deviasi merupakan satu teknik statistik yang digunakan untuk menjelaskan homogenitas kelompok. Varian merupakan jumlah kuadrat semua deviasi nilai-nilai individual terhadap rata-rata kelompok. Sedangkan akar dari varian disebut dengan standar deviasi atau simpangan baku. Standar deviasi dan varians simpangan baku merupakan variasi sebaran data. Semakin kecil nilai sebarannya berarti variasi nilai data makin sama. Jika sebarannya bernilai 0 , maka nilai semua datanya adalah sama. Semakin besar nilai sebarannya berarti data semakin bervariasi. Perhitungan standar deviasi dapat dihitung menggunakan rumus sebagaimana dituliskan Sudjana (2000: 93) sebagai berikut:

$$
\begin{aligned}
& \mathrm{SD}=\sqrt{\mathrm{S}^{2}} \\
& S^{2}=\frac{\sum \mathrm{f}\left(\mathrm{x}_{1}-\overline{\mathrm{X}}\right)^{2}}{\mathrm{~N}} \\
& \text { Keterangan: } \quad=\text { Standar deviasi data. } \\
& \begin{array}{ll}
\mathrm{SD} & =\text { Varian } \\
\mathrm{S}^{2}
\end{array}
\end{aligned}
$$




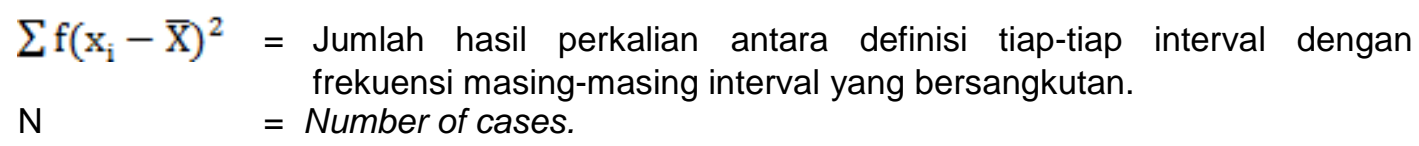

\section{c. Kategorisasi Data}

Kategorisasi data merupakan pengklasifikasian data pada kriteria tertentu. Data-data hasil penelitian ini dikategorikan menjadi Tinggi, Sedang, dan Rendah. Untuk menentukan tinggi, sedang, rendah (Sudijono, 2010: 175) dalam penelitian ini seebagai berikut:

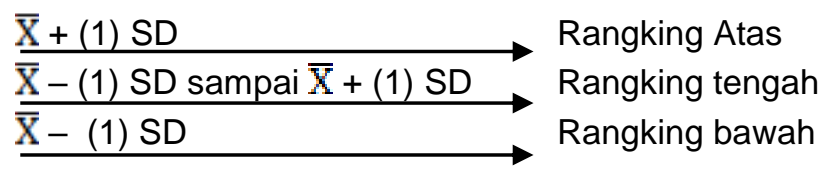

\section{d. Uji Hipotesis}

Hipotesis merupakan kesimpulan sementara penelitian. Hipotesis merupakan jawaban sementara dari rumusan masalah yang diajukan. Andrews (dalam Sangadji, 2010: 90) mengatakan, "Hipotesis adalah suatu jawaban bersifat sementara terhadap permasalahan penelitian sampai terbukti melalui data yang terkumpul". Sudrajat (2005: 167) mengemukakan, "Untuk keperluan analisis perbandingan dua variabel dapat digunakan teknik statistika inferensial yang berupa uji t atau t-test, uji Z maupun uji Kai Kuadrat (Chi Square Test)". Berdasarkan penjelasan tersebut, maka analisis data pada penelitian ini digunakan uji $t$ polled varian adatau sampel berpasangan. Alasan penggunaan uji $t$ polled varian adalah jumlah $\mathrm{n}_{1} \neq \mathrm{n}_{2}$, data pada penelitian ini berdistribusi normal, serta varian data $(\sigma 2)$ diketahui (Sugiyono, 2013:197). Pengujian hipotesis menggunakan uji $t$ polled varian dilakukan menggunakan persamaan berikut:

$$
t=\frac{\bar{X}_{1}-\bar{X}_{2}}{\sqrt{\frac{\left(n_{1}-1\right) S_{1}^{2}+\left(n_{2}-1\right) S_{2}^{2}}{n_{1}+n_{2}-2}\left(\frac{1}{n_{1}}+\frac{1}{n_{2}}\right)}}
$$

$\overline{\mathrm{X}}_{1} \quad=$ Rata-rata skor kelompok eksperimen.

$\overline{\mathrm{X}}_{2} \quad=$ Rata-rata skor kelompok kontrol.

$S^{2} \quad=$ Varian kedua data.

$\mathrm{n}_{1} \quad=$ Jumlah sampel kelompok eksperimen.

$\mathrm{n}_{2} \quad$ = Jumlah sampel kelompok kontrol.

Kriteria pengujian hipotesis adalah terima $\mathrm{H}_{0}$ apabila - $t_{\text {tabel }} \leq t_{\text {hitung }}<+t_{\text {tabel }}$ dan tolak $\mathrm{H}_{0}$ dalam hal lainnya.

\section{HASIL DAN PEMBAHASAN}

Kegiatan penelitian ini dilaksanakan di kelas VIII MTs Nurul Huda Sukaraja. Sesuai desain penelitian yang digunakan yaitu Posttest Only Control Group Design, maka penelitian dilaksanakan di dua kelas yaitu kelas VIII-2 dan kelas VIII-3. Jumlah siswa kelas VIII-2 sebanyak 27 siswa dan ditetapkan sebagai kelas eksperimen yang pembelajarannya menggunakan teknik pembelajaran Value Clarification. Adapun jumlah siswa kelas VIII-3 sebanyak 26 siswa dan ditetapkan sebagai kelas kontrol yang pembelajarannya tanpa menggunakan teknik pembelajaran Value Clarification.

Penelitian dilaksanakan dengan melakukan kegiatan pembelajaran di kelas eksperimen dan di kelas kontrol. Kegiatan pembelajaran di kelas eksperimen yaitu kelas VIII-2 dilakukan selama empat kali pertemuan dengan perincian tiga kali pertemuan untuk menyampaikan materi pembelajaran dan satu kali pertemuan untuk melakukan evaluasi atau tes. Kegiatan pembelajaran di kelas eksperimen dilakukan berdasarkan langkah-langkah pembelajaran menggunakan teknik pembelajaran Value 
Clarification dan diikuti oleh seluruh siswa kelas VIII-2 yang berjumlah 27 siswa. Pada kegiatan pembelajaran peneliti berperan ganda yaitu sebagai peneliti sekaligus sebagai guru. Kegiatan pembelajaran dilakukan berdasarkan pengawasan guru mata pelajaran Aqidah Akhlak setempat.

Kegiatan pembelajaran di kelas kontrol yaitu kelas VIII-3 dilakukan selama empat kali pertemuan dengan perincian tiga kali pertemuan untuk menyampaikan materi pembelajaran dan satu kali pertemuan untuk melakukan evaluasi atau tes. Kegiatan pembelajaran di kelas kontrol dilakukan tanpa menggunakan teknik pembelajaran Value Clarification atau dilakukan berdasarkan rencana pelaksanaan pembelajaran yang telah digunakan sebelum penelitian yaitu menggunakan metode konvensional teknik ceramah plus diskusi dan resitasi. Kegiatan pembelajaran di kelas kontrol diikuti oleh seluruh siswa kelas VIII-3 yang berjumlah 26 siswa. Sebagaimana pada kelas eksperimen, pada kegiatan pembelajaran peneliti berperan ganda yaitu sebagai peneliti sekaligus sebagai guru. Kegiatan pembelajaran dilakukan berdasarkan pengawasan guru mata pelajaran Aqidah Akhlak setempat.

Setelah kegiatan pembelajaran di kedua kelas berakhir yaitu pada pertemuan keempat, dilakukan evaluasi atau tes untuk mengetahui efektivitas kegiatan pembelajaran yang telah dilaksanakan. Tes diberikan dengan cara memberikan soal-soal tertulis berbentuk pilihan ganda sebanyak 20 nomor yang telah memenuhi syarat uji instrumen penelitian. Analisis terhadap hasil tes kedua kelas dapat diuraikan sebagai berikut:

\section{Hasil Belajar Aqidah Akhlak Kelas Eksperimen}

Hasil belajar Aqidah Akhlak siswa yang pembelajarannya menggunakan teknik pembelajaran Value Clarification diketahui menggunakan instrumen tes. Analisis hasil tes menunjukkan bahwa hasil belajar Aqidah Akhlak siswa menggunakan teknik pembelajaran Value Clarification adalah sedang yaitu dari 27 siswa terdapat 8 siswa atau 29,63\% memperoleh nilai kategori tinggi, 18 siswa atau $66,67 \%$ memperoleh nilai kategori sedang dan hanya terdapat 1 siswa atau 3,70\% memperoleh nilai kategori rendah. Data tersebut menunjukkan bahwa hasil belajar Aqidah Akhlak siswa kelas eksperimen yaitu kelas VIII-2 MTs Nurul Huda Sukaraja yang pembelajarannya menggunakan teknik pembelajaran Value Clarification adalah sedang. Hal tersebut karena jumlah siswa yang memperoleh nilai kategori sedang sebesar 66,67\% dimana persentase tersebut telah lebih dari $50 \%$ jumlah siswa seluruhnya.

\section{Hasil Belajar Aqidah Akhlak Kelas kontrol}

Kelas kontrol adalah kelas yang pembelajarannya tanpa menggunakan teknik pembelajaran Value Clarification yaitu kelas VIII-3 dengan jumlah siswa sebanyak 26 orang. Kegiatan pembelajaran dilaksanakan empat kali pertemuan. Setelah kegiatan pembelajaran selesai, peneliti melakukan evaluasi atau tes dengan memberikan soal-soal sebagaimana pada kelas eksperimen. Berdasarkan analisis hasil tes diketahui bahwa dari 26 siswa hanya terdapat 1 siswa atau 3,85\% yang memperoleh nilai kategori tinggi, 19 siswa atau $73,08 \%$ memperoleh nilai kategori sedang, dan terdapat 6 siswa atau 23,08\% memperoleh nilai kategori rendah. Data tersebut menunjukkan bahwa hasil belajar Aqidah Akhlak siswa kelas kontrol yaitu kelas VIII-3 MTs Nurul Huda Sukaraja yang pembelajarannya tanpa menggunakan teknik pembelajaran Value Clarification adalah sedang. Hal tersebut karena jumlah siswa yang memperoleh nilai kategori sedang sebesar $73,08 \%$ dimana persentase tersebut telah lebih dari $50 \%$ dari jumlah siswa seluruhnya.

\section{Hasil Uji Hipotesis}

Setelah masing-masing data hasil tes baik kelas eksperimen menggunakan teknik pembelajaran Value Clarification maupun kelas kontrol teknik pembelajaran Value Clarification diketahui, langkah selanjutnya adalah melakukan uji hipotesis menggunakan uji t. Berdasarkan hasil uji $t$ polled varian diperoleh harga $t_{\text {hitung }}$ sebesar $=5,11$. Angka tersebut kemudian dikonsultasikan dengan nilai $t_{\text {tabel }}$ dengan taraf kepercayaan $95 \%$ dan probabilitas kesalahan sebesar 0,05 dengan $d b=\left(N_{1}+N_{2}-2\right)=27+26-2=51$. Oleh karena pada tabel t tidak diketemukan db 51, maka dilakukan perhitungan menggunakan interpolasi. Berdasarkan 
perhitungan interpolasi di atas diketahui bahwa nilai $t_{\text {tabel }}$ untuk df $27+26-2=51$ adalah 2,01.

Kriteria pengujian hipotesis penelitian ini adalah terima $\mathrm{H}_{0}$ apabila $-t_{\text {tabel }} \leq t_{\text {hitung }}<+t_{\text {tabel }}$ dan tolak $\mathrm{H}_{0}$ dalam hal lainnya. Oleh karena $\mathrm{t}_{\text {hitung }} 5,11$ tidak terletak diantara $-\mathrm{t}_{\text {tabel }} \leq \mathrm{t}_{\text {hitung }}<+\mathrm{t}_{\text {tabel }}$ yaitu $-2,01$ dan $+2,01$ maka $\mathrm{H}_{0}$ yang menyatakan tidak terdapat pengaruh yang signifikan penerapan teknik pembelajaran Value Clarification terhadap hasil belajar Aqidah Akhlak siswa kelas VIII MTs Nurul Huda Sukaraja ditolak, sedangkan $\mathrm{H}_{\mathrm{a}}$ yang menyatakan terdapat pengaruh yang signifikan penerapan teknik pembelajaran Value Clarification terhadap hasil belajar mata pelajaran Aqidah Akhlak materi Iman Kepada Kitab-kitab Allah SWT siswa kelas VIII MTs Nurul Huda Sukaraja diterima. Simpulan analisis data adalah terdapat pengaruh penerapan teknik pembelajaran Value Clarification terhadap hasil belajar mata pelajaran Aqidah Akhlak materi Iman Kepada Kitab-kitab Allah SWT siswa kelas VIII MTs Nurul Huda Sukaraja.

Analisis data hasil tes kedua kelas menunjukkan bahwa meskipun hasil belajar Aqidah Akhlak siswa kelas eksperimen dan kelas kontrol sama-sama dalam kategori sedang, namun hasil belajar Aqidah Akhlak siswa kelas eksperimen dinyatakan lebih baik dari hasil belajar Aqidah Akhlak siswa kelas kontrol. Hasil belajar Aqidah Akhlak siswa kelas VIII MTs Nurul Huda Sukaraja yang pembelajarannya menggunakan teknik pembelajaran Value Clarification lebih baik dari siswa yang pembelajarannya tanpa menggunakan teknik pembelajaran Value Clarification. Hal tersebut terbukti dari tabel persentase yang menunjukkan bahwa pada kelompok siswa yang pembelajarannya menggunakan teknik pembelajaran Value Clarification terdapat 8 siswa atau 29,63\% memperoleh nilai kategori tinggi dan hanya terdapat 1 siswa atau 3,85\% memperoleh nilai kategori tinggi pada kelas tanpa menggunakan teknik pembelajaran Value Clarification. Selain itu, pada kelas menggunakan teknik pembelajaran Value Clarification hanya terdapat 1 siswa atau $3,70 \%$ yang memperoleh nilai ketegori rendah, sedangkan pada kelas tanpa menggunakan teknik pembelajaran Value Clarification terdapat 6 siswa atau 23,08\% memperoleh nilai kategori rendah.

Hasil analisis data sebagaimana tersebut menunjukkan bahwa hasil belajar Aqidah Akhlak siswa kelas VIII-2 MTs Nurul Huda Sukaraja yang pembelajarannya menerapkan teknik pembelajaran Value Clarification lebih baik dibandingkan dengan siswa kelas VIII-3 MTs Nurul Huda Sukaraja yang pembelajarannya tanpa menggunakan teknik pembelajaran Value Clarification. Hal tersebut mengindikasikan bahwa teknik pembelajaran Value Clarification efektif untuk diterapkan pada pembelajaran Aqidah Akhlak di kelas VIII MTs Nurul Huda Sukaraja.

Hasil penelitian menunjukkan bahwa teknik pembelajaran Value Clarification efektif diterapkan pada pembelajaran Aqidah Akhlak di kelas VIII MTs Nurul Huda Sukaraja. Berdasarkan pelaksanaan pembelajaran yang telah dilaksanakan, teknik pembelajaran Value Clarification memberikan berbagai kemudahan bagi siswa untuk memahami materi pembelajaran Aqidah Akhlak yang berisi materi pembelajaran yang sarat nilai berupa nilai aqidah dan nilai akhlak. Hal tersebut sesuai dengan teknik pembelajaran Value Clarification yang dikemukakan Elmubarok (2009: 70) bahwa, "Value Clarification Tecnique atau teknik pembelajaran klarifikasi nilai merupakan teknik pembelajaran yang memberi penekanan usaha membantu siswa mengkaji materi pembelajaran untuk meningkatkan kesadaran akan nilai-nilai yang terkandung pada materi pembelajaran". Teknik pembelajaran Value Clarification merupakan sebuah cara menanamkan danmengungkapkan nilai-nilai tertentu dari siswa. Teknik pembelajaran Value Clarification dilakukan dengan mengupayakan pemahaman siswa terhadap nilai-nilai yang terkandung pada materi pembelajaran.

Hasil penelitian menunjukkan bahwa teknik pembelajaran Value Clarification efektif diterapkan pada pembelajaran Aqidah Akhlak. Teknik pembelajaran Value Clarification sesuai dengan materi pembelajaran Aqidah Akhlak yang merupakan pendidikan nilai yaitu pendidikan yang diselenggarakan untuk menanamkan nilai-nilai ajaran Islam pada diri siswa. Aqidah Akhlak tidak dapat dilaksanakan hanya dengan memberikan pengetahuan terhadap nilai-nilai ajaran agama Islam, namun harus memberikan pemahaman kepada siswa tentang hakikat dari nilai-nilai yang terdapat pada materi Aqidah Akhlak. Dengan demikian Aqidah Akhlak harus dilaksanakan 
menggunakan teknik-teknik tertentu yang sesuai dengan karakteristik Aqidah Akhlak seperti teknik pembelajaran Value Clarification.

\section{PENUTUP}

1 Hasil belajar mata pelajaran Aqidah Akhlak materi Iman Kepada Kitab-kitab Allah SWT siswa yang menerapkan teknik pembelajaran Value Clarification di kelas VIII MTs Nurul Huda Sukaraja adalah sedang yaitu dari 27 siswa terdapat 8 siswa atau 29,63\% memperoleh nilai kategori tinggi, 18 siswa atau $66,67 \%$ memperoleh nilai kategori sedang dan hanya terdapat 1 siswa atau $3,70 \%$ memperoleh nilai kategori rendah dengan nilai rata-rata 78,28.

2 Hasil belajar mata pelajaran Aqidah Akhlak materi Iman Kepada Kitab-kitab Allah SWT siswa yang tidak menerapkan teknik pembelajaran Value Clarification di kelas VIII MTs Nurul Huda Sukaraja adalah sedang yaitu dari 26 siswa hanya terdapat 1 siswa atau 3,85\% yang memperoleh nilai kategori tinggi, 19 siswa atau $73,08 \%$ memperoleh nilai kategori sedang, dan terdapat 6 siswa atau 23,08\% memperoleh nilai kategori rendah dengan nilai rata-rata 66,58.

3 Terdapat pengaruh penerapan teknik pembelajaran Value Clarification terhadap hasil belajar mata pelajaran Aqidah Akhlak materi Iman Kepada Kitab-kitab Allah SWT siswa kelas VIII MTs Nurul Huda Sukaraja dengan nilai $t_{\text {hitung }}=5,11$, sedangkan nilai $t_{\text {tabel }}=2,01$. Karena $t_{\text {hitung }}$ tidak terletak diantara $-t_{\text {tabel }} \leq t_{\text {hitung }}<+t_{\text {tabel }}$ yaitu $-2,01$ dan $+2,01$ maka $H_{o}$ ditolak, sedangkan $\mathrm{H}_{a}$ diterima.

\section{UCAPAN TERIMAKASIH}

Peneliti mengucapkan terima kasih kepada STKIP Nurul Huda Sukaraja Buay Madang OKU Timur, MTs Nurul Huda Sukaraja Kecamatan Buay Madang, dan LPPM STKIP Nurul Huda yang telah memberikan kontribusi dalam penelitian ini.

\section{DAFTAR PUSTAKA}

An-Nawawi, Imam. t.t. Hadis Tarbawi. Semarang: Islamic Center Press.

Arikunto, Suharsimi. 2010. Prosedur Penelitian; Suatu Pendekatan Praktik. Jakarta: Rineka Cipta.

Djahiri, Kosasih. 2007. Teknik-teknik Pembelajaran Inovatif. Bandung: Angkasa.

Elmubarok, Zaim. 2009. Membumikan Pendidikan Nilai. Bandung: Alfabeta.

Hawi, Akmal. 2012. Pendidikan Agama Islam. Palembang: Excellen Publishing.

Hermianto, Wardah. 2017. Perencanaan Pembelajaran. Bandung: CV. Wacana Prima.

Madjid, Nurcholish. 2004. Islam Doktrin dan Peradaban;Sebuah Telaah Kritis Tentang Masalah Keimanan, Kemanusiaan dan Kemodernan. Jakarta: Paramadina.

Margono, S. 2010. Metodologi Penelitian Pendidikan. Jakarta: Rineka Cipta.

Poerwanto, M. Ngalim. 2009. Psikologi Pendidikan. Bandung: Remaja Rosdakarya.

Sanjaya, Wina. 2010. Strategi Pembelajaran Berorientasi Standar Proses Pendidikan. Jakarta: Prenada Media Group.

Sudijono, Anas. 2010. Pengantar Statistik Pendidikan. Jakarta: PT Remaja Rosdakarya.

Sugiyono. 2010. Metode Penelitian Kualitatif, Kuantitatif, dan R\&B. Bandung: Alfabeta.

Suryabrata, Sumadi. 2010. IImu Pendidikan. Jakarta: Raja Grafindo Persada.

Taniredja, Tukiran. 2011. Model-model Pembelajaran Inovatif dan Efektif. Bandung: Alfabeta.

Rukmanah $^{1}$, Suhartono ${ }^{2}$, dan Supangat ${ }^{3}$ 